Arteterapia. Papeles de arteterapia y educación para inclusión social ISSN-e 1988-8309

https://dx.doi.org/10.5209/arte.62164

\title{
El arte reparador de Kader Attia
}

Gonzalo Rodríguez Gómez ${ }^{1}$

Exposición monográfica "Las cicatrices nos recuerdan que nuestro pasado es real" Fundación Joan Miró, Barcelona. 15.06. / 30.09.2018

Muestra organizada por la Fundación Joan Miró y la Obra Social "La Caixa"

«Mantener visibles las heridas es aceptar lo

real. Asi que me dispuse a reparar estas heridas buscando aquello que mi investigación me había enseñado que era fundamental: que la reparación es un oxímoron que también incluye la herida. Negar la herida es mantener el dolor que genera. Al reparar las grietas de la historia con grapas metálicas, con hilo o con

parches de otras culturas, a menudo contradictorias, doy voz a las víctimas; permito que el trauma nos hable y, por lo tanto, allane el camino para la catarsis». Kader Attia. Conferencia en la Fundación Joan Miró. 13 de Junio de 2018, Barcelona

Tras la participación de Kader Attia en la Documenta 13 de Kassel con su obra The Repair from Occident to Extra-Occidental (2012), su práctica artística no ha hecho sino evidenciar el carácter reparador que posee el arte y que genera desde un punto de vista terapéutico o curativo. Parte de sus conclusiones, así como algunas de las claves de su trabajo valoradas por críticos, quedaron reflejadas en el libro de artista "RepaiR", publicado en 2014 por Black Jack Editions y editado por Léa Gauthier y el propio Kader Attia.

Las claves del artista, nacido en 1970 en Dugny (Francia), se describen en "RepaiR" a través de entrevistas realizadas por trece especialistas de arte de distinta formación, y en la que se incluyen además textos de archivos de autores de gran relevancia como Jacques Derrida, Michel Foucault o Hugh Ferriss. A las reflexiones del libro le acompañan unas mil reproducciones fotográficas en blanco y negro, gran parte de ellas sobre el trabajo de Attia en torno al concepto de reparación física y emocional/afectiva.

Tres años después de la publicación de "RepaiR" la Fundación Joan Miró acordó distinguir al artista francoargelino como ganador de la sexta edición del Joan Miró, premio que cada dos años otorga la fundación junto a la Obra Social "La Caixa". En la declaración del acta el jurado valoró "la amplitud de su investigación, el enfoque audaz y sincrético del impacto y los efectos persistentes del colonialismo, así como su elaboración, enciclopédica pero matizada, de la noción de reparación como base de su producción artística. [...] El posicionamiento singular de Attia respecto a la relaciones complejas y a menudo traumáticas entre las culturas humanas resuena igualmente en las aspiraciones universales de Miró”.

1 Universidad de Sevilla. Crítico de arte y miembro de AECA (Asociación Española de Críticos de Arte). gonzbelmez@hotmail.com. 
Con ocasión de este reconocimiento internacional la Fundación Joan Miró programó una muestra monográfica para este año, entre los meses de junio y octubre, donde las principales inquietudes discursivas de Kader Attia se descifraban a nivel curatorial en cuatro grandes salas. La exposición ha contado con algunas de sus obras más reconocidas y también con otras de reciente creación realizadas expresamente para esta muestra monográfica, como pueden ser su pieza audiovisual Héroes heridos, su lienzo titulado Mirrors (2018), o su obra sin título elaborada en los talleres de la Fundación Miró sobre un espejo de gran formato.

De entre sus obras podríamos destacar Open your eyes (2011) [1], una de las piezas de la exposición dedicada a la huella traumática dejada tras algunos de los episodios de la historia más crudos y a los continuos expolios por parte de Occidente. En la obra audiovisual se suceden imágenes de soldados desfigurados durante la I Guerra Mundial y esculturas de madera dañadas e irreconocibles, proyectadas en bucle mediante diapositivas y de forma intermitente hasta generar en el espectador una idea del daño generado en forma de cicatrización.

Durante los años 2007 y 2008 la artista colombiana Doris Salcedo realizó algunas de las obras que expondría más tarde en el Turbine Hall de la Tate Modern, donde su obra Shibboleth acaparó las reacciones y alabanzas más notables. La enorme grieta que imaginó bajo el cemento del museo se convertía en un demoledor relato del sufrimiento y la exclusión a la que sigue siendo sometida gran parte de Latinoamérica. A pesar de su semejanza, la instalación Traditional Repair, Inmaterial Injury, realizada por Kader Attia en 2014 sobre suelo de hormigón y grapas metálicas, parece que mostrara con sus remiendos una forma de reparación con la que conciliar nuestras heridas.

En el texto de presentación de la muestra nos hacían las siguientes preguntas. “¿Cómo abordamos, tanto en el ámbito colectivo como en el personal, el dolor del pasado? ¿Cómo tratamos las heridas? ¿Qué hacemos con los recuerdos? ¿Y cómo planteamos la deuda cultural y social en el entorno con el que interactuamos?". Alguna de las conclusiones de Kader Attia es que en Occidente se ha negado el trauma a través de su ocultación, mientras que en otras culturas las señales originadas física y accidentalmente han sido dignificadas como parte de la historia colectiva e individual.

La práctica artística tiene en Attia un cierto efecto purificador, en el sentido de que es el arte el instrumento mismo que le permite hacer catarsis del dolor al que en ocasiones estamos expuestos. Sus figuras de la serie $J^{\prime}$ acusse en nada tienen que ver con los guerreros de Xi'an, los cuales representaron para la Dinastía Qin un símbolo de protección y fortaleza. Al contrario que este ejército de terracota, las esculturas talladas en madera de Attia muestran sus heridas y malformaciones de igual manera que las víctimas de cualquier masacre, representando su vulnerabilidad pero también recordándonos lo mucho que pueden parecerse a los que somos de carne y hueso.

[1] Kader Attia, Open your eyes. Proyección fotográfica de diapositivas (2 sets), 2011

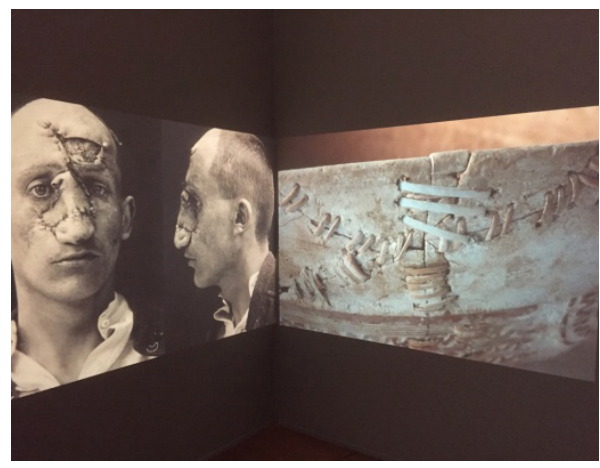

